\title{
Oxidative DNA Damage and Apoptosis Induced by Aclarubicin, an Anthracycline: Role of Hydrogen Peroxide and Copper
}

\author{
HIDEKI MIZUTANI ${ }^{1}$, YUKA HAYASHI ${ }^{1}$, MIYABI HASHIMOTO ${ }^{1}$, MASANORI IMAI ${ }^{1}$, YOSHIMI ICHIMARU $^{1}$, \\ YUKI KITAMURA $^{1}$, KENJI IKEMURA ${ }^{1,2}$, DAISUKE MIYAZAWA ${ }^{1}$, KINYA OHTA $^{1}$, YOSHIAKI IKEDA ${ }^{1}$, \\ TOHRU MAEDA ${ }^{1}$, MASAE YOSHIKAWA ${ }^{1}$, YUSUKE HIRAKU ${ }^{3}$ and SHOSUKE KAWANISHI ${ }^{4}$ \\ ${ }^{1}$ College of Pharmacy, Kinjo Gakuin University, Nagoya, Japan; \\ ${ }^{2}$ Department of Pharmacy, Mie University Hospital, Tsu, Japan; \\ ${ }^{3}$ Department of Environmental Health, University of Fukui School of Medical Sciences, Eiheiji, Japan; \\ ${ }^{4}$ Faculty of Pharmaceutical Sciences, Suzuka University of Medical Science, Suzuka, Japan
}

\begin{abstract}
Background/Aim: This study aimed to investigate aclarubicin (ACR)-induced oxidative DNA damage and apoptosis. Materials and Methods: ACR-induced apoptosis was analyzed using HL-60 leukemia cells and HP100 cells, hydrogen peroxide $\left(\mathrm{H}_{2} \mathrm{O}_{2}\right)$-resistant cells derived from $\mathrm{HL}$ 60 cells. ACR-induced DNA damage was analyzed using plasmid DNA. Results: HL-60 cells were more sensitive to ACR than HP100 cells. In HP100 cells, DNA ladder formation and caspase-3/7 activity induced by ACR were suppressed or delayed in comparison to those in HL-60 cells. ACR-induced DNA damage occurred in the presence of $\mathrm{Cu}(\mathrm{II})$, and scavenger experiments showed that the reactive species causing DNA damage appeared to be generated from $\mathrm{H}_{2} \mathrm{O}_{2}$ and $\mathrm{Cu}(\mathrm{I})$. Moreover, we detected intracellular $\mathrm{Cu}(\mathrm{I})$ induced by ACR in HL-60 cells, using CopperGREEN ${ }^{T M}, a$ fluorescent probe for detection of $\mathrm{Cu}(\mathrm{I})$ ion specifically. Conclusion: ACR-induced DNA damage and apoptosis can be accounted for by the involvement of $\mathrm{H}_{2} \mathrm{O}_{2}$ and $\mathrm{Cu}(\mathrm{I})$.
\end{abstract}

Anthracyclines comprise one of the most important drug classes in anticancer treatment (1). One anthracycline, aclarubicin (aclacinomycin A, ACR), with a trisaccharide chain, was discovered and characterized by Umezawa et al. in the 1970s (2). ACR has potent efficacy against solid as well as hematological malignancies, and shows the same growth inhibition of solid sarcoma-180 and Gardner

This article is freely accessible online.

Correspondence to: Hideki Mizutani, Ph.D., College of Pharmacy, Kinjo Gakuin University, Moriyama-ku, Nagoya 463-8521, Japan. Tel.: +81 527987458, Fax: +81 527980754, e-mail: mizu@kinjo-u.ac.jp

Key Words: Aclarubicin, DNA damage, apoptosis, ROS, hydrogen peroxide, copper.
6C3HED/OG lymphosarcoma transplanted subcutaneously in mice as doxorubicin and daunorubicin (3). The cardiotoxicity of ACR is weaker than that of doxorubicin in hamsters (4). ACR is clinically approved in Japan for treatment of cancer of the stomach, lung, breast and ovary, as well as acute leukemia and malignant lymphoma; ACR is often used in place of daunorubicin or idarubicin to reduce cardiotoxicity in patients with acute myeloid leukemia and myelodysplastic syndrome (5-7).

It is believed that the main anticancer action of anthracyclines is apoptosis through DNA damage (1). ACRinduced DNA damage is caused by inhibition of topoisomerase I and II, and by DNA intercalation and the action of reactive oxygen species (ROS) (8-11). It has been reported that ACR induced DNA damage and apoptosis, one cause of which was ROS generation $(12,13)$. However, the mechanism of ACRinduced ROS generation has not well been elucidated. In this study, we investigated apoptosis induced by ACR using human leukemia cell lines, HL-60, and HP100, a hydrogen peroxide $\left(\mathrm{H}_{2} \mathrm{O}_{2}\right)$-resistant clone derived from HL-60 cell line $(14,15)$. The apoptotic mechanisms were analyzed by examining cell viability assay, DNA ladder assay and caspase-3/7 activity assay. We also examined ACR-induced DNA damage using plasmid DNA and $\mathrm{O}_{2}{ }^{-}$production in the presence of $\mathrm{Cu}(\mathrm{II})$ in a cell-free system. In addition, we detected intracellular $\mathrm{Cu}(\mathrm{I})$ induced by ACR using a fluorescent probe to detect $\mathrm{Cu}(\mathrm{I})$ ion specifically in HL-60 cells.

\section{Materials and Methods}

Materials. Aclarubicin hydrochloride was purchased from FUJIFILM Wako Pure Chemical Co. (Osaka, Japan). Superoxide dismutase (SOD; 3,000 U/mg from bovine erythrocytes), catalase $(45,000 \mathrm{U} / \mathrm{mg}$ from bovine liver) and cytochrome $\mathrm{c}$ (from equine heart) were purchased from Sigma-Aldrich Co. (St. Louis, MO, USA). Plasmid DNA (pBR322) and DNA gel loading dye (6x) were from Toyobo Co. (Osaka, Japan). Copper chloride $\left(\mathrm{CuCl}_{2} \cdot 2 \mathrm{H}_{2} \mathrm{O}\right)$ 
A

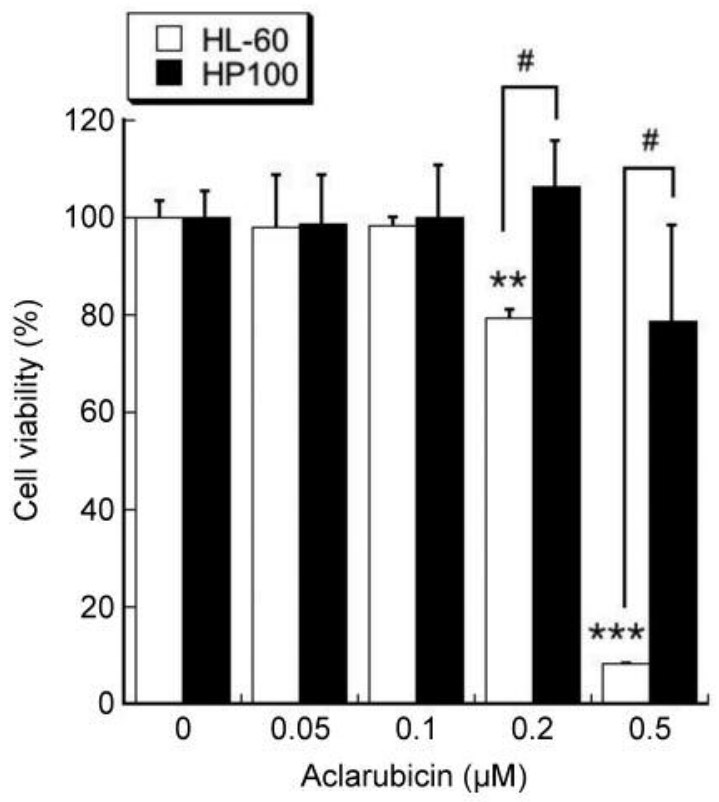

B $24 \mathrm{~h}$

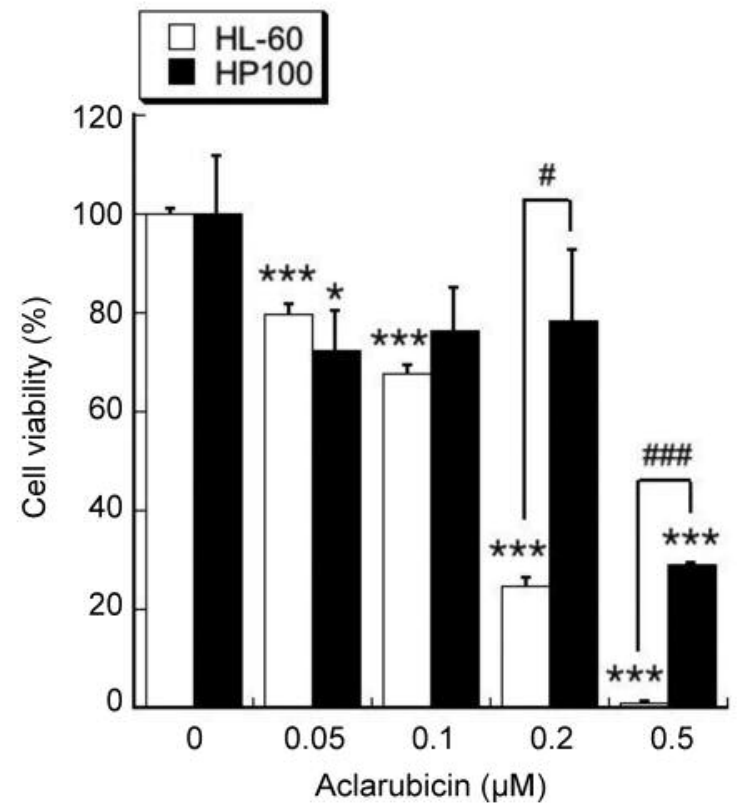

Figure 1. Determination of cell viability in HL-60 and HP100 cells after treatment with aclarubicin (ACR) for $6(A)$ and $24 \mathrm{~h}(\mathrm{~B})$. After treatment, cell viability was determined by the luminescent assay kit. The data are presented as means $\pm S D(n=3)$. Significantly different at: $* p<0.05$, ** $p<0.01$

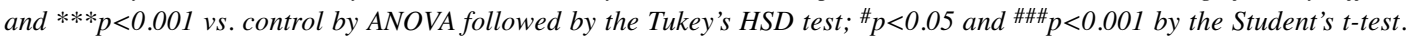

was from Nacalai Tesque Co. (Kyoto, Japan). Diethylenetriamine$N, N, N^{\prime}, N$ ', $N$ ''-penta-acetic acid (DTPA) and bathocuproinedisulfonic acid were from Dojindo Laboratories Co. (Kumamoto, Japan). Methional [3-(Methylthio)propionaldehyde] was from Tokyo Chemical Industry Co. (Tokyo, Japan). CopperGREEN ${ }^{\mathrm{TM}}$, a fluorescent probe used to detect $\mathrm{Cu}(\mathrm{I})$ ions, was from Goryo Chemical Inc. (Sapporo, Japan). All other chemicals used were of the highest purity commercially available.

Cell culture and treatment with ACR. Human leukemia HL-60 and HP100 cells were obtained from Riken BioResource Research Center (Tsukuba, Japan). HP100 cells have approximately 340 -fold higher resistance to $\mathrm{H}_{2} \mathrm{O}_{2}$ (14) and 18 times higher catalase activity (15) than HL-60 cells. By use of HP100 cells, effects of intracellular catalase can be evaluated (16). HL-60 and HP100 cells were grown in RPMI 1640 (FUJIFILM Wako Pure Chemical Co.) supplemented with $6 \%$ fetal bovine serum (Biowest Co., Nuaillé, France) at $37^{\circ} \mathrm{C}$ under $5 \% \mathrm{CO}_{2}$ in a humidified atmosphere. The cells $\left(0.5 \times 10^{6}\right.$ or $1 \times 10^{6}$ cells $\left./ \mathrm{ml}\right)$ were then treated with $0.05,0.1$, 0.2 and $0.5 \mu \mathrm{M}$ of ACR.

Determination of cell viability treated by ACR in HL-60 and HP100 cells. A luminescent assay kit quantitating the ATP present (CellTiter-Glo ${ }^{\circledR}$ Assay, Promega, Fitchburg, WI, USA) was used for determining the number of viable cells in culture. A total of $5.0 \times 10^{4}$ cells were seeded into each well of 96-well white cell culture plates (Thermo Fisher Scientific, Waltham, MA, USA). After ACR (0.05, $0.1,0.2$ and $0.5 \mu \mathrm{M})$ treatment for $6 \mathrm{~h}$ or $24 \mathrm{~h}$, the cell viability was analyzed according to the manufacturer's explanatory notes.
Detection of ACR-induced apoptosis of HL-60 and HP100 cells. For analyses of DNA ladder formation in treated cells by ACR, cells were washed twice with phosphate-buffered saline (PBS). The fragmented DNA was extracted from HL-60 and HP100 cells $\left(2 \times 10^{6}\right.$ cells) according to previous reports $(17,18)$. DNA ladder formation was analyzed by conventional electrophoresis.

Analysis of caspase-3/7 activity in HL-60 and HP100 cells. A total of $5.0 \times 10^{4}$ cells were seeded into each well of 96 -well black cell culture plates (Thermo Fisher Scientific). After ACR treatment $(0.05,0.1,0.2$ and $0.5 \mu \mathrm{M})$ for $6 \mathrm{~h}$, caspase- $3 / 7$ activity was analyzed use of a caspase-3/7 activity fluorescent assay kit (Apo$\mathrm{ONE}^{\circledR}$ Homogeneous Caspase-3/7 Assay; Promega, Fitchburg, WI, USA) according to the manufacturer's explanatory notes.

Analysis of ACR-induced DNA damage in the presence of $C u(I I)$ in a cell-free system. The standard reaction solution in a $1.5 \mathrm{ml}$ Eppendorf Tubes ${ }^{\circledR} 3810 \mathrm{X}$ (Eppendorf AG, Hamburg, Germany) contained ACR, $20 \mu \mathrm{M} \mathrm{CuCl}_{2}$ and pBR322 plasmid DNA $(0.2 \mu \mathrm{g} /$ tube $)$ in $50 \mu \mathrm{l}$ of $10 \mathrm{mM}$ sodium phosphate buffer ( $\mathrm{pH} 7.8$ ) containing $5 \mu \mathrm{M}$ DTPA, a chelator, for removal of trace amounts of contaminating metals. After incubation at $37^{\circ} \mathrm{C}$ for $60 \mathrm{~min}$, DNA gel loading dye was added to the reaction solution and the reacted DNA was electrophoresed on a $0.7 \%$ agarose gel containing ethidium bromide. The obtained DNA gels were analyzed using a UV transilluminator $(19,20)$.

Analysis of ACR-induced DNA damage in the presence of metals in a cell-free system. The reaction solution placed in a $1.5 \mathrm{ml}$ Eppendorf Tubes ${ }^{\circledR} 3810 \mathrm{X}$ contained $20 \mu \mathrm{M}$ ACR, $20 \mu \mathrm{M}$ metals 
A

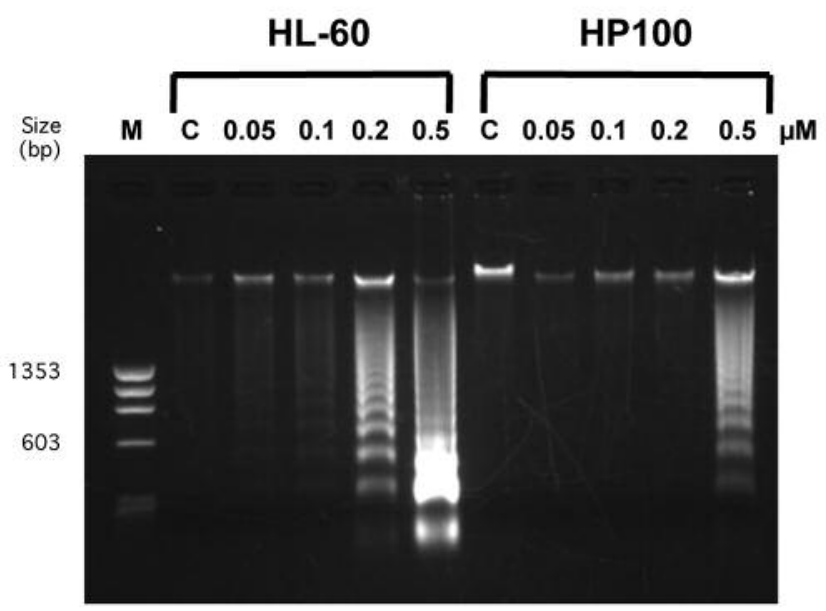

B

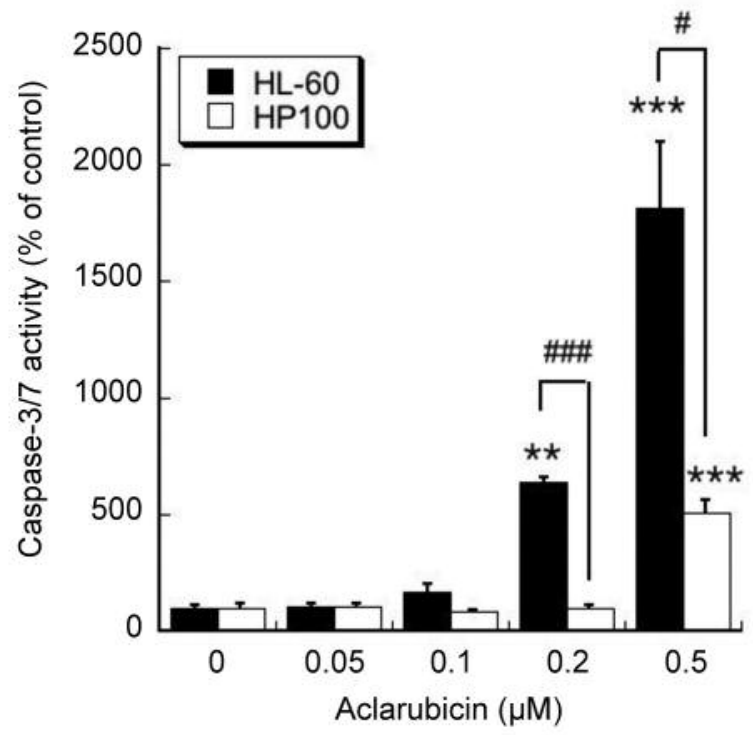

Figure 2. Detection of aclarubicin (ACR)-induced apoptosis of HL-60 and HP100 cells. A: DNA ladder formation in HL-60 and HP100 cells after treatment with ACR for $6 \mathrm{~h}$. The DNA was extracted from cell lysate and analyzed by conventional electrophoresis. Marker line: Size marker DNA (\$X174/Hae III digest). B: Caspase-3/7 activation in HL-60 and HP100 cells treated with ACR for 6 h. After ACR treatment, caspase-3/7 activity was determined by caspase-3/7 activity assay kit. The data are presented as means $\pm S D(n=3)$. Significantly different at: $* * p<0.01$ and $* * * p<0.001$ vs. control by ANOVA followed by the Tukey's HSD test; ${ }^{p} p<0.05$ and ${ }^{\# \# \# ~} p<0.001$ by the Student's $t$-test.

$\left(\mathrm{CuCl}_{2}, \mathrm{FeCl}_{3}, \mathrm{FeSO}_{4}\left(\mathrm{NH}_{4}\right)_{2} \mathrm{SO}_{4}, \mathrm{ZnSO}_{4}, \mathrm{NiSO}_{4}, \mathrm{MgCl}_{2}, \mathrm{CoCl}_{2}\right.$ or $\left.\mathrm{MnCl}_{2}\right)$ and pBR322 plasmid DNA $(0.2 \mu \mathrm{g} /$ tube $)$ in $50 \mu \mathrm{l}$ of $10 \mathrm{mM}$ sodium phosphate buffer ( $\mathrm{pH} 7.8)$ containing $5 \mu \mathrm{M}$ DTPA. After incubation at $37^{\circ} \mathrm{C}$ for $60 \mathrm{~min}$, the DNA gel loading dye was added to the reaction solution and the reacted DNA was electrophoresed on a $0.7 \%$ agarose gel containing ethidium bromide. The obtained DNA gels were analyzed by using a UV transilluminator (20).

Analysis of effects of ROS scavengers and bathocuproine on ACRinduced DNA damage in the presence of $C u(I I)$ in a cell-free system. The reaction solution placed in a $1.5 \mathrm{ml}$ Eppendorf Tubes ${ }^{\circledR}$ $3810 \mathrm{X}$ contained $20 \mu \mathrm{M}$ ACR, $20 \mu \mathrm{M} \mathrm{CuCl}_{2}$, pBR322 plasmid DNA $(0.2 \mu \mathrm{g} /$ tube $)$ in $50 \mu \mathrm{l}$ of $10 \mathrm{mM}$ sodium phosphate buffer (pH 7.8) containing $5 \mu \mathrm{M}$ DTPA with ROS scavengers and $50 \mu \mathrm{M}$ bathocuproine, as a $\mathrm{Cu}(\mathrm{I})$-chelating agent. ROS scavengers were $1.7 \mathrm{M}(10 \%)$ ethanol, $0.1 \mathrm{M}$ mannitol, $0.1 \mathrm{M}$ sodium formate, $0.7 \mathrm{M}(10 \%)$ dimethyl sulfoxide (DMSO), 50 or 100 units of SOD, 50 or 100 units of catalase, and $0.1 \mathrm{M}$ methional. After incubation at $37^{\circ} \mathrm{C}$ for $60 \mathrm{~min}$, the DNA gel loading dye was added to the reaction solution and the reacted DNA was electrophoresed on a $0.7 \%$ agarose gel stained with ethidium bromide. The obtained DNA gels were analyzed by using a UV transilluminator (20).

Detection of $\mathrm{O}_{2}{ }^{-}$derived from $\mathrm{ACR}$ in the presence of $\mathrm{Cu}(\mathrm{II})$ in a cell-free system. To detect $\mathrm{O}_{2}{ }^{--}$generation from ACR, $100 \mu \mathrm{M}$ cytochrome $c$ was added to a reaction solution containing $20 \mu \mathrm{M}$ ACR and $20 \mu \mathrm{M} \mathrm{Cu}$ (II) in $1 \mathrm{ml}$ of $10 \mathrm{mM}$ sodium phosphate buffer (pH 7.8) with $2.5 \mu \mathrm{M}$ DTPA. The reduction of ferricytochrome $\mathrm{c}$ produces ferrocytochrome $c$ that has an absorption maximum at
$550 \mathrm{~nm}$; absorption was measured at $37^{\circ} \mathrm{C}$ with a UV-visible spectrophotometer (UV-2600; Shimadzu, Kyoto, Japan). The actual amount of reduced cytochrome $c$ was calculated by subtracting absorbance with $100 \mathrm{U} / \mathrm{ml} \mathrm{SOD}$ from that without SOD at $550 \mathrm{~nm}$ $\left(\varepsilon=21.1 \times 10^{3} \mathrm{M}^{-1} \mathrm{~cm}^{-1}\right)(20,21)$.

Determination of intracellular $C u(I)$ induced by ACR in HL-60 cells. CopperGREEN $^{\mathrm{TM}}$, a fluorescent probe for detection of $\mathrm{Cu}(\mathrm{I})$ ions, was used to determine intracellular $\mathrm{Cu}(\mathrm{I})$ in cultured cells (22). HL60 cells $\left(1 \times 10^{6}\right.$ cells) were treated with ACR at $37^{\circ} \mathrm{C}$ for $3 \mathrm{~h}$ in the presence of $5 \mu \mathrm{M}$ CopperGREEN ${ }^{\mathrm{TM}}$. Cells were then washed twice with PBS. After resuspension in PBS, cells were analyzed using a fluorescence microscopy (EVOS ${ }^{\circledR}$ FLoid ${ }^{\circledR}$ Cell Imaging Station; Thermo Fisher Scientific). Obtained data were analyzed using Image J 1.43u (National Institute of Health, Bethesda, MD, USA).

Statistical analysis. All statistical analyses were performed using Kaleida Graph version 4.1.3 (Synergy Software, Reading, PA, USA). ANOVA followed by Tukey's HSD test was used to compare differences between the test groups and the control groups. Student's $t$-test was used to compare differences between the test groups. Values of $p<0.05$ were regarded as statistically significant.

\section{Results}

Cell viability in HL-60 and HP100 cells treated with ACR. We determined cell viability in the cells treated with ACR by use of CellTiter-Glo ${ }^{\circledR}$ assay. As shown in Figure 1, HL-60 cells were significantly more sensitive to $0.2 \mu \mathrm{M}$ and $0.5 \mu \mathrm{M}$ 


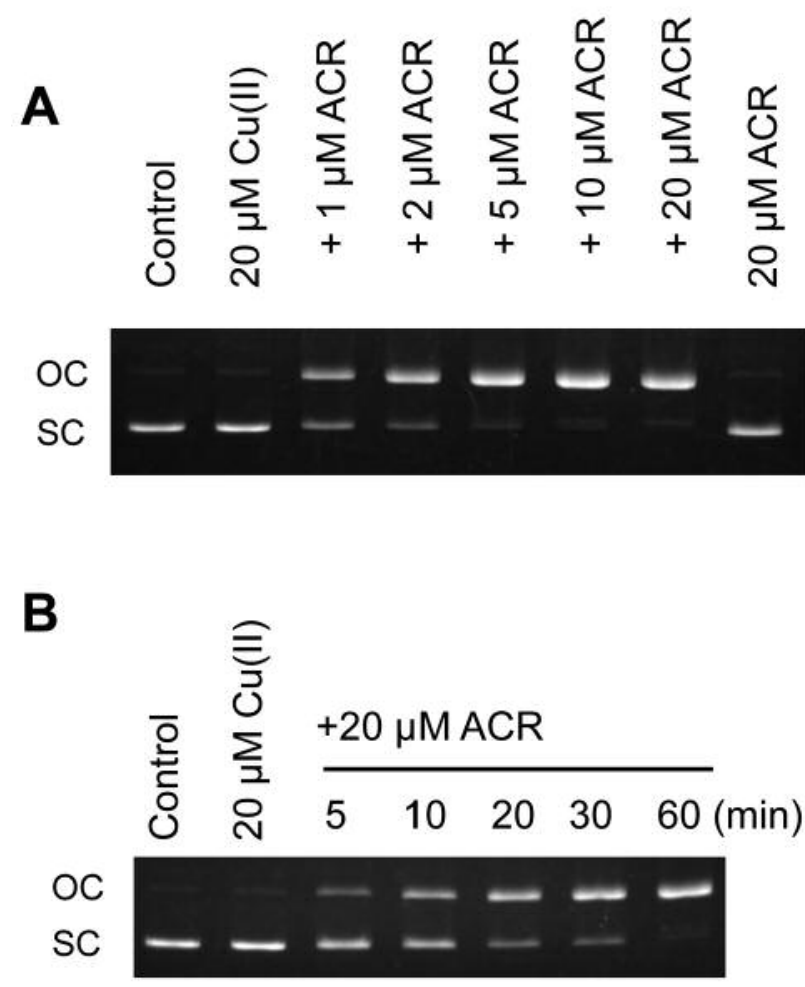

Figure 3. Analysis of aclarubicin (ACR)-induced DNA damage in the presence of $\mathrm{Cu}(\mathrm{II})$. A: Plasmid pBR322 DNA was treated with the indicated concentrations of $A C R$ in the presence of $20 \mu M \mathrm{CuCl}_{2}$ for 1 h. B: Plasmid pBR322 DNA was treated with $20 \mu M A C R$ in the presence of $20 \mu \mathrm{MCuCl}$ for the indicated times. The supercoiled (SC) and open circular $(O C)$ forms of DNA are indicated.

ACR than were HP100 cells after 6-h and 24-h incubation. The cytotoxicity of 24-h ACR treatment was higher than that of 6-h ACR treatment.

DNA ladder assay in HL-60 and HP100 cells treated with $A C R$. After treatment with ACR, DNA ladder formation, which reflects apoptotic events, was analyzed using conventional electrophoresis. In HL-60 cells, ACR-induced DNA ladder formation was detected after 6-h incubation with 0.2 and $0.5 \mu \mathrm{M}$, while it was only detected at $0.5 \mu \mathrm{M}$ in HP100 cells (Figure 2A).

Caspase-3/7 activity in HL-60 and HP100 cells after ACR treatment. ACR-induced apoptosis was assessed by caspase3/7 activity. The caspase-3/7 activity after 6-h ACR treatment was remarkably increased at 0.2 and $0.5 \mu \mathrm{M}$ in HL-60 cells $(0.2 \mu \mathrm{M}, p<0.01 ; 0.5 \mu \mathrm{M}, p<0.001)$, and at $0.5 \mu \mathrm{M}$ in HP100 cells $(p<0.001)$. Caspase-3/7 in HL-60 cells had significant higher activity than that in HP100 cells at 0.2 and $0.5 \mu \mathrm{M}$ (Figure 2B) $(0.2 \mu \mathrm{M}, p<0.001 ; 0.5 \mu \mathrm{M}, p<0.05)$.
A

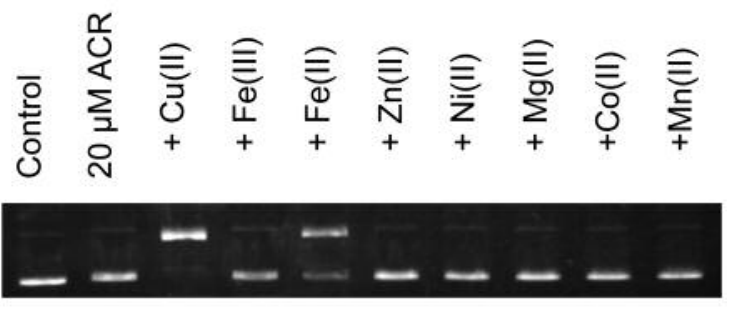

B

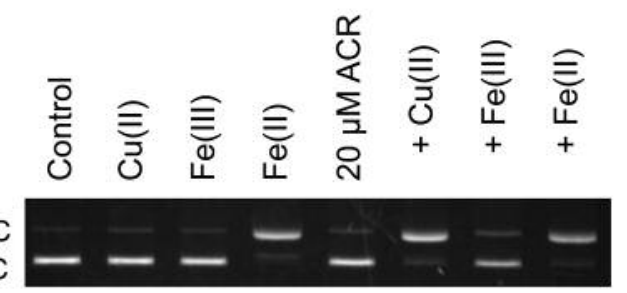

Figure 4. Analysis of aclarubicin (ACR)-induced DNA damage in the presence of metals in a cell-free system. A: Plasmid pBR322 DNA was treated with $20 \mu \mathrm{MACR}$ in the presence of $20 \mu \mathrm{M}$ a metal $\left(\mathrm{CuCl}_{2}\right.$, $\mathrm{FeCl}_{3}, \mathrm{FeSO}_{4}\left(\mathrm{NH}_{4}\right)_{2} \mathrm{SO}_{4}, \mathrm{ZnSO}_{4}, \mathrm{NiSO}_{4}, \mathrm{MgCl}_{2}, \mathrm{CoCl}_{2}$ or $\mathrm{MnCl}_{2}$ ) 1 h. B: Plasmid pBR322 DNA was treated with $20 \mu \mathrm{M}$ metal and $20 \mu \mathrm{M}$ $A C R$ for $1 \mathrm{~h}$. The supercoiled (SC) and open circular (OC) forms of $D N A$ are indicated.

These events were in good agreement with DNA ladder formation induced by ACR.

$A C R$-induced DNA damage in the presence of $C u(I I)$. Figure 3 shows agarose gel electrophoretic DNA cleavage patterns of plasmid DNA pBR322 after ACR treatment. The intensity of DNA damage increased depending on the ACR concentration in the presence of $\mathrm{Cu}$ (II) (Figure 3A). ACR induced DNA damage at $1 \mu \mathrm{M}$ and clear strong DNA damage above $2 \mu \mathrm{M}$ in the presence of $\mathrm{Cu}(\mathrm{II})$. ACR or $\mathrm{Cu}$ (II) did not induce DNA damage alone. The intensity of ACR-induced DNA damage also increased dependent on incubation time in the presence of $\mathrm{Cu}(\mathrm{II})$. DNA damage was induced by $\mathrm{ACR}$ at $5 \mathrm{~min}$ in the presence of $\mathrm{Cu}$ (II) (Figure 3B). On the other hand, DNA damage was not caused by $\mathrm{ACR}$ in the presence of $\mathrm{Fe}(\mathrm{III}), \mathrm{Zn}$ (II), Ni(II), $\mathrm{Mg}$ (II), $\mathrm{Co}$ (II) or Mn(II) (Figure 4A). Moreover, since Fe(II) alone induced DNA damage, it is suggested that ACR itself may not cause DNA damage in the presence of Fe(II) (Figure 4B).

Effects of ROS scavengers and bathocuproine on ACRinduced DNA damage in the presence of $C u(I I)$. The effects of ROS scavengers and bathocuproine on ACR-induced DNA damage in the presence of $\mathrm{Cu}$ (II) in the cell-free system using plasmid DNA pBR322 are shown in Figure 5. Little or no inhibition of DNA damage induced by ACR was 


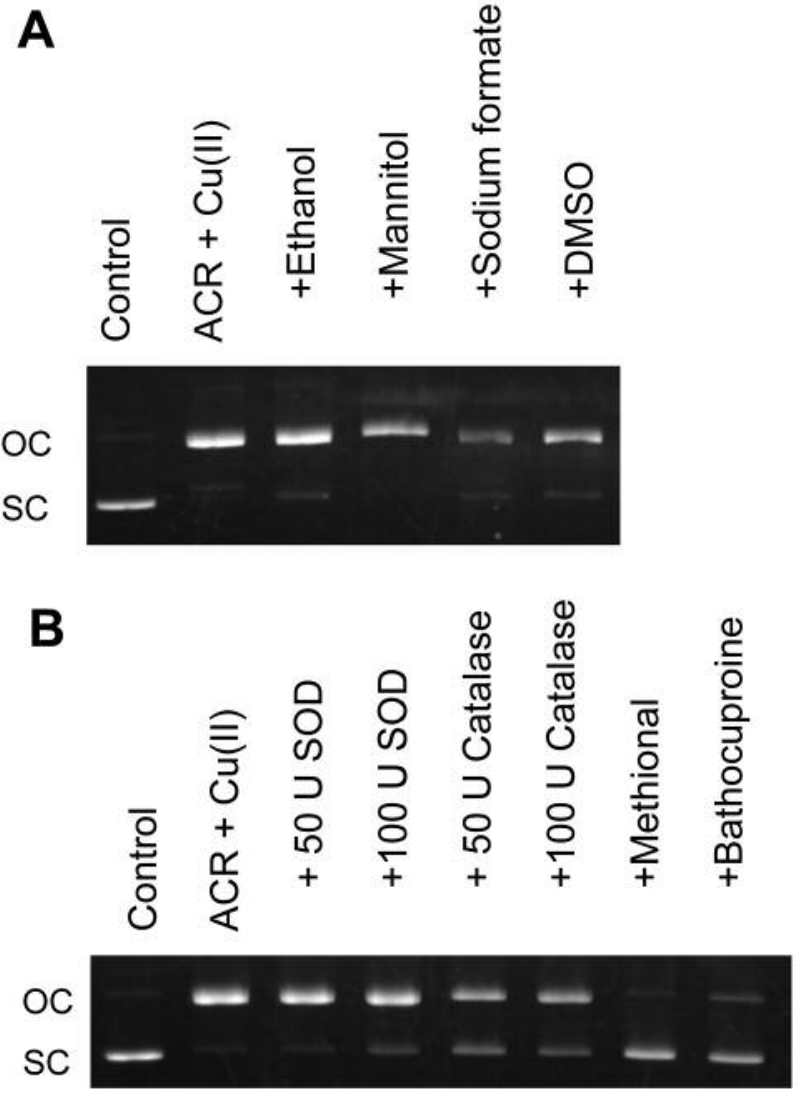

Figure 5. Inhibition by scavengers of reactive oxygen species (ROS) and bathocuproine, a Cu(I)-chelating agent, of aclarubicin (ACR)-induced $D N A$ cleavage in the presence of $\mathrm{Cu}(\mathrm{II})$. A: Plasmid pBR322 DNA was treated with $20 \mu \mathrm{M} A C R$ in the presence of $\mathrm{Cu}(\mathrm{II})(20 \mu \mathrm{M})$ for $1 \mathrm{~h}$ with and without $1.7 \mathrm{M}(10 \%)$ ethanol, $0.1 \mathrm{M}$ mannitol, $0.1 \mathrm{M}$ sodium formate, $0.7 \mathrm{M}(10 \%)$ dimethyl sulfoxide (DMSO), 50 or 100 units of superoxide dismutase (SOD), 50 or 100 units of catalase, $0.1 \mathrm{M}$ methional, or $50 \mu \mathrm{M}$ bathocuproine was added. The supercoiled (SC) and open circular (OC) forms of DNA are indicated.

found after incubation with typical $\bullet \mathrm{OH}$ scavengers, ethanol, mannitol, sodium formate and DMSO (Figure 5A). SOD and catalase inhibited DNA damage induced by ACR. Methional and bathocuproine completely inhibited DNA damage induced by ACR (Figure 5B).

Detection of $\mathrm{O}_{2}{ }^{--}$derived from ACR in the presence of $\mathrm{Cu}(\mathrm{II})$ in a cell-free system. Figure 6 shows the production of reduced cytochrome $c$ as a result of ACR in the presence $\mathrm{Cu}(\mathrm{II})$. The presence of ACR and $\mathrm{Cu}(\mathrm{II})$ led to a timedependent increase in reduced cytochrome $c$. The quantity of reduced cytochrome $c$ decreased with the addition of SOD, reflecting the production of $\mathrm{O}_{2}{ }^{\circ-}$. From these results, the quantity of $\mathrm{O}_{2}{ }^{\circ-}$ produced by $20 \mu \mathrm{M}$ ACR was about $1.4 \mu \mathrm{M}$ in the presence of $20 \mu \mathrm{M} \mathrm{Cu}(\mathrm{II})$. The inhibition of

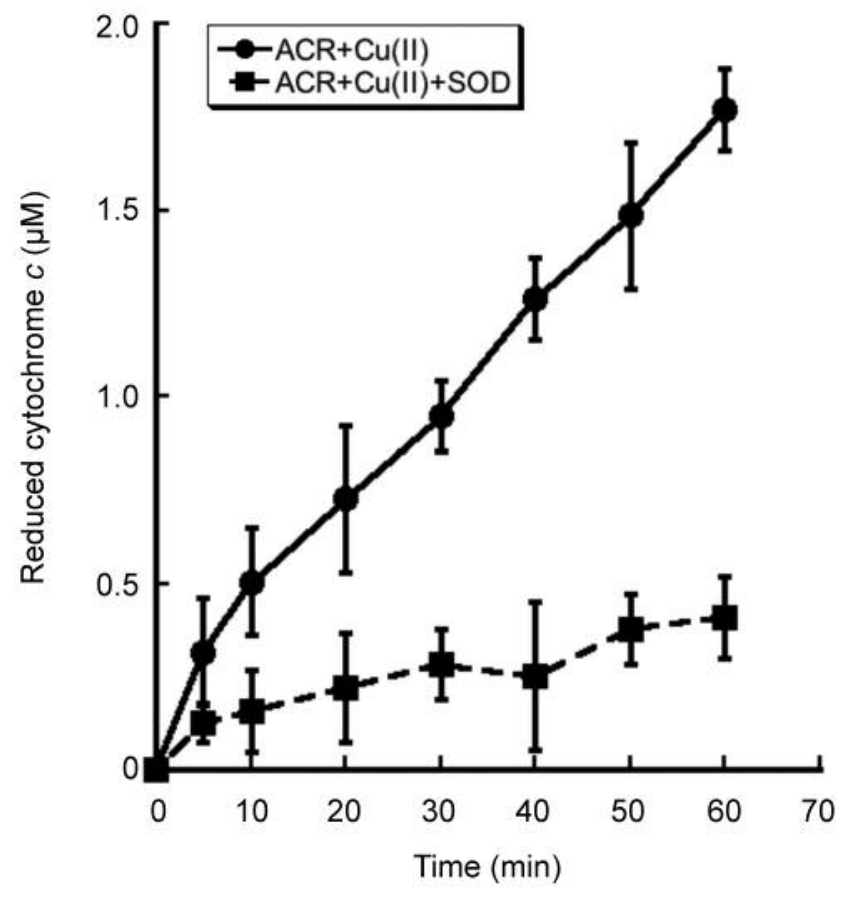

Figure 6. Temporal pattern of the production of reduced cytochrome $c$ with aclarubicin $(A C R)$ in the presence of $\mathrm{Cu}(\mathrm{II})$. The reaction solution contained $100 \mu \mathrm{M}$ cytochrome c, $20 \mu \mathrm{M}$ ACR and $20 \mu \mathrm{M} \mathrm{Cu}(\mathrm{II})$. Absorption at $550 \mathrm{~nm}$ was measured at $37^{\circ} \mathrm{C}$ with a spectrophotometer. The actual amount of reduced cytochrome $c$ was calculated by subtracting absorbance with $100 \mathrm{U} / \mathrm{ml}$ superoxide dismutase (SOD) from that without SOD at $550 \mathrm{~nm}\left(\varepsilon=21.1 \times 10^{3} \mathrm{M}^{-1} \mathrm{~cm}^{-1}\right)$. The data are presented as means $\pm S D(n=3)$.

cytochrome $c$ reduction by SOD was only partial, it suggests that there are $\mathrm{O}_{2}{ }^{-}$-independent mechanisms of reduction of cytochrome $c$, possibly mediated by $\mathrm{Cu}(\mathrm{I})(20,23)$.

Determination of intracellular $\mathrm{Cu}(\mathrm{I})$ in $\mathrm{HL}-60$ cells treated with $A C R$. Figure 7 shows intracellular $\mathrm{Cu}(\mathrm{I})$ detection induced by ACR in HL-60 cells. We used CopperGREEN ${ }^{\mathrm{TM}}$, a green fluorescent probe for detection of $\mathrm{Cu}(\mathrm{I})$ ions specifically, in order to determine intracellular $\mathrm{Cu}(\mathrm{I})$ in cultured cells (22). The results showed that ACR treatment coincided with an increase in $\mathrm{Cu}(\mathrm{I})$-positive cells in a dose-dependent manner.

\section{Discussion}

In this study, we showed ACR induced apoptosis of both HL-60 cells and HP100 cells, the $\mathrm{H}_{2} \mathrm{O}_{2}$-resistant clone of HL-60. ACR-induced cytotoxicity, DNA ladder formation and caspase-3/7 activity of HP100 cells were suppressed, in comparison with that of HL-60 cells. HP100 cells have approximately 340 -fold higher resistance to $\mathrm{H}_{2} \mathrm{O}_{2}$ than HL60 cells (14). Therefore, these observations can be explained 
by the mediation of $\mathrm{H}_{2} \mathrm{O}_{2}$ production in the apoptotic mechanism induced ACR. Our previous reports have shown that doxorubicin and pirarubicin induce oxidative DNA damage by $\mathrm{H}_{2} \mathrm{O}_{2}$ production, followed by mitochondrial dysfunction and subsequent activation of caspase-3/7, resulting in apoptosis $(16,24)$. Therefore, these observations show the possibility that oxidative DNA damage by $\mathrm{H}_{2} \mathrm{O}_{2}$ production induces apoptosis.

In order to verify the mechanism of DNA damage, we demonstrated that ACR induced oxidative DNA damage of plasmid DNA in the presence of $\mathrm{Cu}$ (II) in a cell-free system. DNA damage was inhibited by SOD and catalase, suggesting the involvement of $\mathrm{O}_{2}{ }^{--}$and $\mathrm{H}_{2} \mathrm{O}_{2}$. Bathocuproine entirely inhibited DNA damage, since bathocuproine prevents $\mathrm{H}_{2} \mathrm{O}_{2}$ activation by chelating $\mathrm{Cu}(\mathrm{I})(25,26)$. This suggests that $\mathrm{Cu}(\mathrm{I})$ is involved in DNA damage. As typical $\bullet \mathrm{OH}$ scavengers (ethanol, mannitol, sodium formate and DMSO) did not prevent DNA damage, it is suggested that free $\bullet \mathrm{OH}$ is not involved in DNA damage induced by ACR. Methional completely inhibited DNA damage. Methional inhibits not only $\bullet \mathrm{OH}$ but also other radicals, for example, metal-oxygen complexes (27). Hence, $\mathrm{Cu}(\mathrm{II})$-mediated DNA damage appears to be due to ROS such as $\mathrm{Cu}(\mathrm{I}) \mathrm{OOH}$. Moreover, we demonstrated that ACR generated $\mathrm{O}_{2}{ }^{-}$in the presence of $\mathrm{Cu}(\mathrm{II})$, suggesting that $\mathrm{ACR}$ and $\mathrm{Cu}(\mathrm{II})$ produced $\mathrm{Cu}(\mathrm{I})$, which reacted with $\mathrm{O}_{2}$ to produce $\mathrm{O}_{2}{ }^{-}$and subsequently $\mathrm{H}_{2} \mathrm{O}_{2}$. In addition, we revealed that ACR treatment generated intracellular $\mathrm{Cu}(\mathrm{I})$ using a fluorescent probe that specifically detects $\mathrm{Cu}(\mathrm{I})$ in HL-60 cells.

We previously demonstrated that doxorubicin and pirarubicin induced oxidative DNA damage in the presence of $\mathrm{Cu}$ (II) through oxidation of its $p$-hydroquinone moiety by copper ion $(20,23)$. ACR has an anthraquinone moiety similar to doxorubicin and pirarubicin. Therefore, it appears that ACR induces oxidative DNA damage in the presence of $\mathrm{Cu}$ (II) in a similar way to that of doxorubicin and pirarubicin. We propose the mechanism of ACR-induced oxidative DNA damage to be as follows: ACR undergoes $\mathrm{Cu}$ (II)-mediated one-electron oxidation at the $\mathrm{OH}$ group on the anthraquinone aromatic moiety to produce $\mathrm{Cu}(\mathrm{I})$ and the semiquinone radical. $\mathrm{Cu}(\mathrm{I})$ undergoes $\mathrm{O}_{2}{ }^{--}$production from $\mathrm{O}_{2}$, subsequently generating $\mathrm{H}_{2} \mathrm{O}_{2}$. DNA binding to produce $\mathrm{Cu}(\mathrm{I})$ interacts with $\mathrm{H}_{2} \mathrm{O}_{2}$, resulting in the formation of DNA-copper-hydroperoxo complex [DNA-Cu(I)OOH] (Figure 8). Although typical $\bullet \mathrm{OH}$ scavengers did not prevent DNA damage, $\bullet \mathrm{OH}$ may be involved in DNA damage mediated by the formation of $\mathrm{DNA}-\mathrm{Cu}(\mathrm{I}) \mathrm{OOH}$, which can release $\bullet \mathrm{OH}$ in the proximity of DNA. $\bullet \mathrm{OH}$ readily attacks an adjacent component of DNA, before it is inhibited by -OH scavengers $(20,23)$. Moreover, we demonstrated that ACR treatment generated intracellular $\mathrm{Cu}(\mathrm{I})$ in HL-60 cells, confirming that $\mathrm{Cu}(\mathrm{I})$ has important roles in ACR-induced DNA damage and apoptosis.

\section{Bright field CopperGREEN}

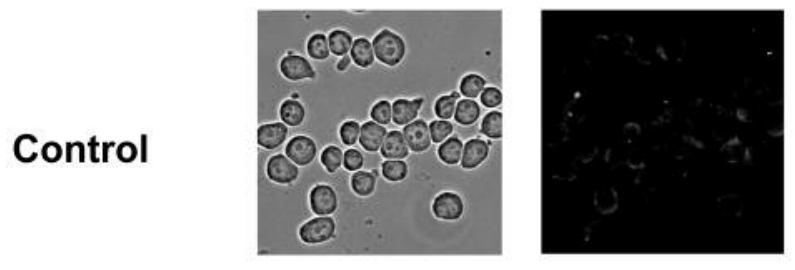

ACR $0.2 \mu \mathrm{M}$
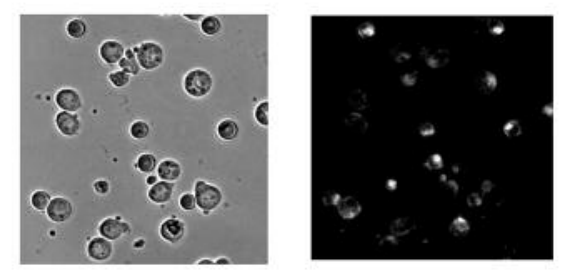

\section{ACR $0.5 \mu \mathrm{M}$}
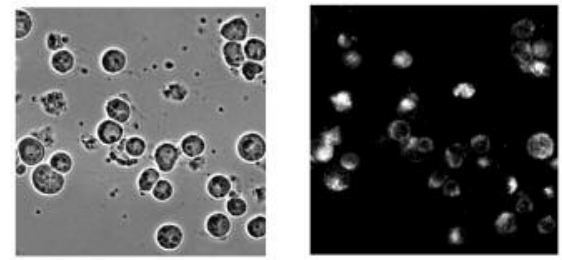

Figure 7. Determination of intracellular $\mathrm{Cu}(\mathrm{I})$ generation induced by aclarubicin (ACR) in HL-60 cells. HL-60 cells $\left(1 \times 10^{6}\right.$ cells $)$ were treated with ACR for $3 \mathrm{~h}$ in the presence of $5 \mu \mathrm{M}$ CopperGREEN ${ }^{T M}, a$ fluorescent probe used to detect $\mathrm{Cu}(\mathrm{I})$ ion. Cells were washed twice with phosphate-buffered saline (PBS). After resuspension in PBS, cells were analyzed by fluorescence microscopy.

Furthermore, it is reported that $40 \mu \mathrm{M}$ of copper exist in the nucleus of the normal mouse hepatocytes $(28,29)$. DNA has greater affinity for copper ions than for other essential metal ions $(29,30)$. These findings suggest that ACR with intracellular copper may induce oxidative DNA damage in cells. Our and other groups reported that anticancer agents (doxorubicin, pirarubicin, hydroxyurea, procarbazine, cyclophosphamide, dacarbazine, 6-mercaptopurine, methotrexate and etoposide) in the presence of copperinduced oxidative DNA damage in a cell-free system $(20,23$, 31-37). Previous reports described that anthracyclines induced ROS generation and oxidative DNA damage in the presence of iron $(38,39)$, whereas we demonstrated that $\mathrm{H}_{2} \mathrm{O}_{2}$ production and copper also have important roles in DNA-damaging and apoptotic activity of anthracyclines. Therefore, oxidative DNA damage, mediated by $\mathrm{H}_{2} \mathrm{O}_{2}$ production and copper, followed by apoptosis may be an important general anticancer mechanism for anthracyclines.

\section{Conflicts of Interest}

The Authors have no conflicts of interest to declare. 


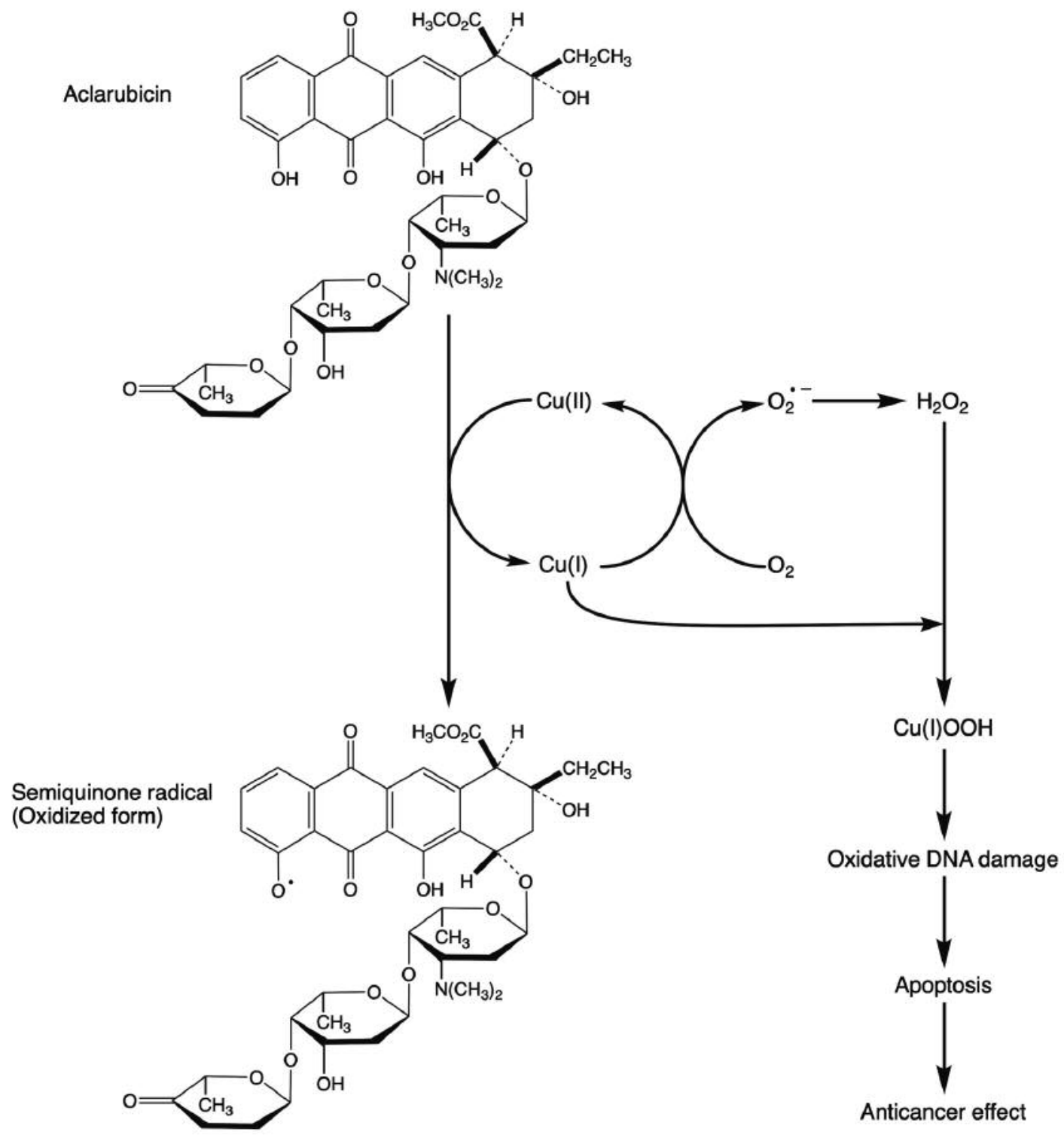

Figure 8. Probable mechanisms for oxidative DNA damage and apoptosis induced by aclarubicin in the presence of Cu(II).

\section{Authors' Contributions}

H.M., Y. Hayashi, M.H. and Y. Ichimaru contributed to the experimental work; all Authors participated in data analysis; H.M. and S.K. conceived and coordinated the study; H.M., Y. Hiraku and S.K. drafted the article. All Authors gave final approval for publication.

\section{Acknowledgements}

This work was supported by JSPS KAKENHI Grant Number 25460229 and $16 \mathrm{~K} 08420$.

\section{References}

1 Wellstein A: Section VIII. Pharmacotherapy of Neoplastic Diseases. In: Brunton LL, Hilal-Dandan R and Knollmann BC (eds.): Goodman and Gilman's: The Pharmacological Basis of Therapeutics, 13th Edition. McGraw Hill. pp. 1159-1248, 2018.

2 Oki T, Matsuzawa Y, Yoshimoto A, Numata K, Kitamura I, Hori S, Takamatsu A, Umezawa H, Ishizuka M, Naganawa H, Suda $\mathrm{H}$, Hamada $\mathrm{M}$ and Takeuchi T: New antitumor antibiotics, aclacinomycins A and B. J Antibiot 28: 830-834, 1975. PMID: 1184473. DOI: 10.7164/antibiotics.28.830 
3 Hori S, Shirai M, Hirano S, Oki T, Inui T, Tsukagoshi S, Ishizuka M, Takeuchi $\mathrm{T}$ and Umezawa $\mathrm{H}$ : Antitumor activity of new anthracycline antibiotics, aclacinomycin-A and its analogs, and their toxicity. Gan 68: 685-690, 1977. PMID: 579346.

4 Wakabayashi $\mathrm{T}$, Oki $\mathrm{T}$, Tone $\mathrm{H}$, Hirano $\mathrm{S}$ and Omori $\mathrm{K}$ : A comparative electron microscopic study of aclacinomycin and adriamycin cardiotoxicities in rabbits and hamsters. J Electron Microsc 29: 106-118, 1980. PMID: 6933206.

5 Wei G, Ni W, Chiao JW, Cai Z, Huang H and Liu D: A metaanalysis of CAG (cytarabine, aclarubicin, G-CSF) regimen for the treatment of 1029 patients with acute myeloid leukemia and myelodysplastic syndrome. J Hematol Oncol 4: 46, 2011. PMID: 22082134. DOI: $10.1186 / 1756-8722-4-46$

6 Fukushima T, Kawabata H, Sawaki T, Satoh T, Nakamura T, Iwao H, Nakajima A, Sakai T, Miki M, Fujita Y, Tanaka M, Kawanami T, Masaki Y, Okazaki T and Umehara H: Low-dose cytarabine plus aclarubicin for patients with previously untreated acute myeloid leukemia or high-risk myelodysplastic syndrome ineligible for standard-dose cytarabine plus anthracycline. Anticancer Res 32: 1347-1353, 2012. PMID: 22493369.

7 Minakata D, Fujiwara S, Ito S, Mashima K, Umino K, Nakano H, Kawasaki Y, Sugimoto M, Yamasaki R, Yamamoto C, Ashizawa M, Hatano K, Okazuka K, Sato K, Oh I, Ohmine K, Suzuki T, Muroi K and Kanda Y: A low-dose cytarabine, aclarubicin and granulocyte colony-stimulating factor priming regimen versus a daunorubicin plus cytarabine regimen as induction therapy for older patients with acute myeloid leukemia: A propensity score analysis. Leuk Res 42: 82-87, 2016. PMID: 26790727. DOI: 10.1016/j.leukres.2015.12.013

8 Larsen AK, Escargueil AE and Skladanowski A: Catalytic topoisomerase II inhibitors in cancer therapy. Pharmacol Ther 99: 167-181, 2003. PMID: 12888111. DOI: 10.1016/S0163-7258 (03)00058-5

9 Misumi M, Yamaki H, Akiyama T and Tanaka N: Mechanism of action of aclacinomycin A II. The interaction with DNA and with tubulin. J Antibiot 32: 48-52, 1979. PMID: 761992. DOI: 10.7164/antibiotics. 32.48

10 Ando S, Kamiya K, Yoshimura T, Tsutani H, Ueda T, Uchida M, Nakamura $\mathrm{T}$ and Uchino H: DNA-binding characteristics of aclarubicin as compared with daunorubicin and doxorubicin. Anticancer Res 8: 409-415, 1988. PMID: 3164610.

11 Rogalska A, Koceva-Chyła A and Jóźwiak Z: Aclarubicininduced ROS generation and collapse of mitochondrial membrane potential in human cancer cell lines. Chem Biol Interact 176: 58-70, 2008. PMID: 18692031. DOI: 10.1016/ j.cbi.2008.07.002

12 Kania K, Zych A and Jóźwiak Z: Involvement of reactive oxygen species in aclarubicin-induced death of human trisomic and diabetic fibroblasts. Toxicol In Vitro 21: 1010-1019, 2007. PMID: 17459657. DOI: 10.1016/j.tiv.2007.02.013

13 Rogalska A, Szwed M and Jóźwiak Z: Aclarubicin-induced apoptosis and necrosis in cells derived from human solid tumours. Mutat Res 700: 1-10, 2010. PMID: 20399885. DOI: 10.1016/j.mrgentox.2010.04.013

14 Kasugai I and Yamada M: Adaptation of human leukemia HL60 cells to hydrogen peroxide as oxidative stress. Leuk Res 13: 757-762, 1989. PMID: 2796382. DOI: 10.1016/0145-2126(89) 90088-X
15 Kasugai I and Yamada M: High production of catalase in hydrogen peroxide-resistant human leukemia HL-60 cell lines. Leuk Res 16: 173-179, 1992. PMID: 1312186. DOI: 10.1016/ 0145-2126(92)90129-U

16 Mizutani H, Hotta S, Nishimoto A, Ikemura K, Miyazawa D, Ikeda Y, Maeda T, Yoshikawa M, Hiraku Y and Kawanishi S: Pirarubicin, an anthracycline anticancer agent, induces apoptosis through generation of hydrogen peroxide. Anticancer Res 37: 6063-6069, 2017. PMID: 29061786. DOI: 10.21873/anticanres. 12054

17 Hiraku Y and Kawanishi S: DNA damage and apoptosis induced by benzene metabolites. Cancer Res 56: 5172-5178, 1996. PMID: 8912853

18 Mizutani H, Tada-Oikawa S, Hiraku Y, Oikawa S, Kojima M and Kawanishi S: Mechanism of apoptosis induced by a new topoisomerase inhibitor through the generation of hydrogen peroxide. J Biol Chem 277: 30684-30689, 2002. PMID: 12068 015. DOI: $10.1074 /$ jbc.M204353200

19 Ohnishi S, Mizutani H and Kawanishi S: The enhancement of oxidative DNA damage by anti-diabetic metformin, buformin, and phenformin, via nitrogen-centered radicals. Free Radic Res 50: 929-937, 2016. PMID: 27328723. DOI: 10.1080/10715 762.2016 .1204651

20 Mizutani H, Nishimoto A, Hotta S, Ikemura K, Imai M, Miyazawa D, Ohta K, Ikeda Y, Maeda T, Yoshikawa M, Hiraku $\mathrm{Y}$ and Kawanishi S: Oxidative DNA damage induced by pirarubicin, an anthracycline anticancer agent, in the presence of copper(II). Anticancer Res 38: 2643-2648, 2018. PMID: 29715084. DOI: 10.21873 /anticanres.12506

21 Mizutani H, Hiraku Y, Tada-Oikawa S, Murata M, Ikemura K, Iwamoto T, Kagawa Y, Okuda M and Kawanishi S: Romidepsin (FK228), a potent histone deacetylase inhibitor, induces apoptosis through the generation of hydrogen peroxide. Cancer Sci 101: 2214-2219, 2010. PMID: 20624163. DOI: 10.1111/ j.1349-7006.2010.01645.x

22 Taki M, Iyoshi S, Ojida A, Hamachi I and Yamamoto Y: Development of highly sensitive fluorescent probes for detection of intracellular copper(I) in living systems. J Am Chem Soc 132: 5938-5939, 2010. PMID: 20377254. DOI: 10.1021/ja100714p

23 Mizutani H, Oikawa S, Hiraku Y, Murata M, Kojima M and Kawanishi S: Distinct mechanisms of site-specific oxidative DNA damage by doxorubicin in the presence of copper(II) and NADPH-cytochrome P450 reductase. Cancer Sci 94: 686-691, 2003. PMID: 12901793.

24 Mizutani H, Tada-Oikawa S, Hiraku Y, Kojima $M$ and Kawanishi S: Mechanism of apoptosis induced by doxorubicin through the generation of hydrogen peroxide. Life Sci 76: 14391453, 2005. PMID: 15680309. DOI: 10.1016/j.lfs.2004.05.040

25 Jewett SL, Rocklin AM, Ghanevati M, Abel JM and Marach JA: A new look at a time-worn system: oxidation of CuZn-SOD by $\mathrm{H}_{2} \mathrm{O}_{2}$. Free Radic Biol Med 26: 905-918, 1999. PMID: 10232834 .

26 Burkitt MJ: A critical overview of the chemistry of copperdependent low density lipoprotein oxidation: roles of lipid hydroperoxides, alpha-tocopherol, thiols, and ceruloplasmin. Arch Biochem Biophys 394: 117-135, 2001. PMID: 11566034. DOI: 10.1006/abbi.2001.2509

27 Pryor WA and Tang RH: Ethylene formation from methional. Biochem Biophys Res Commun 81: 498-503, 1978. PMID: 666768. 
28 Ralle M, Huster D, Vogt S, Schirrmeister W, Burkhead JL, Capps TR, Gray L, Lai B, Maryon E and Lutsenko S: Wilson disease at a single-cell level: Intracellular copper trafficking activates compartment-specific responses in hepatocytes. J Biol Chem 285: 30875-30883, 2010. PMID: 20647314. DOI: 10.1074/jbc.M110.114447

29 Linder MC: The relationship of copper to DNA damage and damage prevention in humans. Mutat Res 733: 83-91, 2012. PMID: 23463874.

30 Burkitt MJ: Copper--DNA adducts. Methods Enzymol 234: 6679, 1994. PMID: 7808340.

31 Sakano K, Oikawa S, Hasegawa $\mathrm{K}$ and Kawanishi S: Hydroxyurea induces site-specific DNA damage via formation of hydrogen peroxide and nitric oxide. Jpn J Cancer Res 92: 1166-1174, 2001. PMID: 11714440.

32 Ogawa K, Hiraku Y, Oikawa S, Murata M, Sugimura Y, Kawamura J and Kawanishi S: Molecular mechanisms of DNA damage induced by procarbazine in the presence of $\mathrm{Cu}$ (II). Mutat Res 539: 145-155, 2003. PMID: 12948823.

33 Murata M, Suzuki T, Midorikawa K, Oikawa S and Kawanishi S: Oxidative DNA damage induced by a hydroperoxide derivative of cyclophosphamide. Free Radic Biol Med 37: 793-802, 2004. PMID: 15304255. DOI: 10.1016/j.freerad biomed.2004.05.009

34 Iwamoto T, Hiraku Y, Okuda M and Kawanishi S: Mechanism of UVA-dependent DNA damage induced by an antitumor drug dacarbazine in relation to its photogenotoxicity. Pharm Res 25 : 598-604, 2008. PMID: 17710513. DOI: 10.1007/s11095-0079413-2
35 Rehman SU, Zubair H, Sarwar T, Husain MA, Ishqi HM, Nehar $\mathrm{S}$ and Tabish M: Redox cycling of $\mathrm{Cu}(\mathrm{II})$ by 6-mercaptopurine leads to ROS generation and DNA breakage: Possible mechanism of anticancer activity. Tumour Biol 36: 1237-1244, 2015. PMID: 25344215. DOI: 10.1007/s13277-014-2743-x

36 Nagaj J, Kołkowska P, Bykowska A, Komarnicka UK, Kyzioł A and Jeżowska-Bojczuk $\mathrm{M}$ : Interaction of methotrexate, an anticancer agent, with copper(II) ions: coordination pattern, DNA-cleaving properties and cytotoxic studies. Med Chem Res 24: 115-123, 2015. PMID: 25589824.

37 Sinha BK, Antholine WM, Kalyanaraman B and Eliot HM: Copper ion-dependent oxy-radical mediated DNA damage from dihydroxy derivative of etoposide. Biochim Biophys Acta 1096: 81-83, 1990. PMID: 2176549.

38 Stěrba M, Popelová O, Vávrová A, Jirkovský E, Kovaříková P, Geršl V and Simůnek T: Oxidative stress, redox signaling, and metal chelation in anthracycline cardiotoxicity and pharmacological cardioprotection. Antioxid Redox Signal 18: 899-929, 2013. PMID: 22794198. DOI: 10.1089/ars.2012.4795

39 Gammella E, Maccarinelli F, Buratti P, Recalcati S and Cairo G: The role of iron in anthracycline cardiotoxicity. Front Pharmacol 5: 25, 2014. PMID: 24616701. DOI: 10.3389/fphar.2014.00025

Received April 27, 2019

Revised June 4, 2019

Accepted June 7, 2019 